\title{
Political Extremism and Separatism: Brief Review and Analysis of Studies
}

\author{
Nikolay P. Medvedev ${ }^{1}$, Dmitry E. Slizovskiy ${ }^{1}$, Hafizullah Jawad ${ }^{1,2}$, Randah Madingue ${ }^{3} \&$ Nguyen Thi Hoang \\ $\mathrm{Oanh}^{3}$ \\ ${ }^{1}$ Faculty of Humanities and Social Sciences, Peoples' Friendship University of Russia (RUDN University), \\ Russia \\ ${ }^{2}$ Faculty of Law and Political Science, Herat University, Afghanistan \\ 3 Department of Political Analysis and Management, People' Friendship University of Russia (RUDN \\ University), Russia \\ Correspondence: Nikolay P. Medvedev, Faculty of Humanities and Social Sciences, Peoples' Friendship \\ University of Russia (RUDN University), Russia. E-mail: medvedev_d@mail.ru
}

Received: March 15, 2020

doi:10.5539/jpl.v13n2p144
Accepted: April 21, $2020 \quad$ Online Published: May 25, 2020

URL: https://doi.org/10.5539/jpl.v13n2p144

\begin{abstract}
The article presents a brief review of the studies of political extremism and separatism and the processes associated with them published in Russian and English over the past 10 years. In the center of the analysis is an attempt to describe the specifics and features of the dominant centers for the formation of a new academic and propaganda language that creates the content of ideas about the modern stage of separatism. The results of the study show that the current stage of the global world order and thinking form a different scale and priorities of the reasons and motives for the separatism use. The structure and significance of separatism factors and ideas about it change, but the content of power and politics and the dominant groups of influence, do not change. The separatism tension points have shifted from the traditional causes and motives for the growth of separatist sentiment to a combination of crude and veiled support for separatism and the use of its potential on a global scale by the governments of the leading countries. The process of reformatting the consciousness and politics of the supporters of separatism, who have created their own nation-states, has gained momentum.
\end{abstract}

Keywords: political extremism, political separatism, nationalism, federalism

\section{Focus of Relevance}

The relevance of separatism in all its manifestations is natural, if only because in critical time there are few mechanisms other than separatism, which could compete for the mobilization of society on the basis of migration processes, ethnic, religious and cultural identities. The processes of separation or division, primarily regional separatism, have become central and painful in Western Europe (Italy, Spain, France, and Belgium) (https: //networks.h-net.org/node/3911/discussions/90459/secessionism-and-separatism-monthly-series-secession. 2019). In Ukraine, separatism has turned into a civil war between the Kiev government and the military-administrative structures of the unrecognized Donetsk and Lugansk People's Republics. Even at places, where separatism is less intense, one can find its signs and manifestations (https://www.thefreedictionary.com/separatism). Separatism has become a part of politics and political processes of social and party-political movements and entities and territories seeking full autonomy or statehood in Africa, Asia and Latin America. National liberation struggle in Africa and conflicts in many countries are supported by external global forces. We are witnessing a new wave of anti-nationalist insurgencies in Africa (http://opiniojuris.org/2019/06/20/the-increasing-involvement-of-european-institutions-in-the-case-against-catala n-separatists\%EF\%BB\%BF. 2019). Hong Kong's "localism" and separatism in the interpretation of Chinese experts is called the "black revolution," and it became a warning about the importance of building and developing an ideology related to the motto "one country, two systems" (Ryabinin, Y. 2017). While over the past few decades, Latinos suffered from drug trafficking, guerrilla terrorism and inter-state wars, traditional separatist movements have not been as visible here, as in Africa, the Middle East, Asia or Europe. Latin America avoided separatism of the type that occurred after the collapse of the USSR or Yugoslavia. But minimal presence of separatist movements in Latin American distorts the realities in the region 
(https://papers.ssrn.com/sol3/papers.cfm?abstract_id=3316715. 2019). In some places, including Russia, separatist movements stopped short before tipping the scales either towards violent methods or staying in line with purely political actions.

Today, socio-political and economic tensions even in relatively prosperous countries are a good basis for the growth of political extremism and separatist sentiments and for the study of separatism and in such its form as political separatism. At the same time, separatism in its various manifestations is not fully studied by scientists, researchers, analysts, politicians and the population. For example, romanticism and classicism of the beliefs in Europe as a leading model of integration and social justice for all its citizens does not seem to be a solid basis even for those politicians who are facing a new wave of separatist sentiments and actions. Had it been different, Spanish Prime Minister Pedro Sanchez would not have had to declare with anger in November 2019 after an outbreak of an ongoing Catalan separatism: "No state would ever allow the unilateral secession of a territory that is part of its constitutional order. And no democrat should support the path chosen by Catalonia's separatist leaders, who won less than $48 \%$ of the votes cast in regional elections" (Sanchez Pedro.2019). The insistent calls of politicians like Pedro Sanchez to speak and listen to each other, to engage in dialogue, "if the separatist leaders abandon their unilateral path" do not find a reasonable response. We can ask why. Back in 2013, researcher Ivan Serano, using the example of Catalan separatism, pointed out to the importance of identity in explaining the aspiration for independence, but he also pointed out to the fact that "it is widely supported in Catalan society because it offers a much more complex relationship" (Serrano Ivan. 2019).

For the moment, theorists and conceptualists of separatism and their opponents do not see those more difficult relations concerning separatism. And they endlessly teach each other about the fallacy of their opinions. While in their heads various conflicts mix together, the intricacy and complexity of solving problems and contradictions in an atmosphere of aggravated separatism (or of what is only a representation of it!?) are evident even when in situations fundamentally different in their nature, when the same requirement is repeated, it seems very simple and easily feasible, but it's so only at first glance. This is the requirement: "Spain, sit down and talk" (See: Thieß Petersen. Separatism in Europe. 2019). It seems that not so much slogans and declarations, as the forcing of separatists and opponents of separatism around the world, in all countries, to sit down and talk, to enter into a dialogue, should become the concern of international organizations, the governments of the leading countries, of all ruling parties or parties fighting for power. This is what the Minsk Agreements are about (a truce, withdrawal of forces, the beginning of dialogue about the elections in Donbass, amnesty to the conflict participants and then "restoration of full control over the state border by the Ukrainian government in all conflict zones"). The same is said in some areas of Donetsk and Lugansk regions of Ukraine. Is it still Ukraine!? If you follow the Minsk Agreements (http://blogs.7iskusstv.com/?p=49194) And if these Agreements are still implemented. Will the agreements and requirements be implemented in Spain or Ukraine, if the opponents do not sit down and talk? And if they do not agree!? In the meantime, not in Spain, but in Ukraine and around the Ukrainian "separatism" we hear rigid statements and distrust: a) "it is necessary to re-establish a new, truly "independent" Ukraine. This should be done by a free resolution of all its territories. And at the same time the right of regions not to enter the new state should be recognized. That would be fair," (Medvedev N. P., Kamara S. 2018) noted D. Pushilin, Head of the DNR, not really thinking what others may think about it. But, it turns out that this passage is an answer to the statements from Kiev: "the Ukrainian side stressed that the implementation of the political bloc of the Minsk Agreements is possible only if the following points are fulfilled: the dissolution of the DPR and LPR quasi-groups" (http://www.un/org/ru/documents/charter. 1997). In Kiev, they see the problem as it should be seen by necessity and by the nature of Ukrainians. Donetsk and Lugansk do not want to be measured with this most "svidomo" Ukrainians.

Therefore, the persistence in upholding the once self-imposed separatism and extremism by all their subjects is not a deep necessity, but stubbornness. Or is it both? And there would be no sadness if each side only stated its views. There are no attempts to persuade each other, to talk and convince. Hard and bitter recipes and political devices are more acceptable to their sensual minds.

The focus of the relevance of separatism today, in our opinion, has moved from the field of views about the belonging of separatism to the essence of the modern world order and globalization to the explanation of the positions of those who are for the modern world order and globalization, but are strongly against separatism of some and separatism of others. At the same time, there is no clear explanation and understanding why the actions of some "FOR" and others "AGAINST" separatism are condemned, or, on the contrary, strongly supported and approved. Probably it is this logic of interpretation of the processes and phenomena, and separatism, in particular, a reflection and consequence of some serious damage to the collective consciousness and mind that French President Macron associated with the "brain death of NATO" (https://rusnext.ru/news/1571167149. 2019), with 
the brain death of NATO for the moment!

All those who like President Macron, Prime Minister of Spain Sanchez or President of Ukraine Zelensky are eager to expose the unsightly situation in the understanding of what is happening, should probably remind others that the era of change, hints and half-hints, including on the role and importance of extremism and separatism and its apologists, will last on a global scale for years and decades, but not centuries or more. During this time, the scientific community and politicians can create a new political culture, a new language of dialogue and communication, in which extremism and separatism will be a consolation and satisfaction of the urgent needs of those who today rely on separatism. Doubts on this score are more than legitimate and justified. The issues of this order are relevant and put on the agenda not only practically, but also theoretically. But in both aspects there can be illusions and ambiguity, a mixture of popularity and populism.

\section{The Popularity and Populism of Separatism: Narratives of Background}

Meanwhile, separatism permeates even everyday life, concerns the fate of millions of people on all continents of the planet. In comments about separatism in the blogosphere one can often find the same, frightening perception of separatism: "nepotism, favoritism and separatism are the biggest threat to the survival of any organized culture on the planet" (Bill Thomas.2019). This opinion, if it is recognized as a widespread and universal opinion in groups of public influence is not necessarily the opinion of a "Cabinet man," but rather the opposite. This is the opinion of people who know firsthand the tragedy and vulgarity of separatism. But nearby, right there, a researcher or a person interested in separatism meets an absolutely different interpretation of the role and value of separatism. Thus, Jane Jacobs, Canadian-American writer, activist, urban planning theorist and one of the founders of the new urbanism movement, published a book in 1980 (/ https://www.tandfonline.com/doi/full/10.1080/17449057. 2012), which addresses not only the specific question of Quebec and Canada, but also the broader question of sovereignty and autonomy in general. Using Norway as a model, Jacobs details that country's campaign of peaceful tenacity that led to the severing of its ties with Sweden. She suggests that Canada and Canadians be inspired by this example.

People with such judgments, as we believe, tend to separatist subjectivism, to the naive belief that separatism contains either something negative or positive. They are excited and attracted by both sides. But the main thing in which they believe is that through separatism you can cut the knot of modern contradictions, separating yourself from the obvious and far-fetched problems and threats. Among such people and among the separatists we can find diehard exponents of both separatism and supporters in the sense that is enshrined in international law (https://www.thefreedictionary.com/separatism) and international treaties (Ryabinin, Y. 2017). The contradictions between Unitarians, federalists and separatists, "integrators" and "fragmentators," between self-determination up to secession and self-determination, between quasi-criminal conflicts and acts of forced self-determination are not as confusing as they seem in the scientific world. The versatility, dynamic fluidity and in fact, the nebula and confusion in the analysis of political extremism and separatism in our opinion satisfy many scientists, scientific analytical centers and online forums (Separatism in Ukraine etc, 2019), and, of course, certain political forces both in the centers, centers of separatism, and outside. Isn't that so!? The contrast in the definition of the content, new forms, role and meanings of extremism and separatism can be confirmed by dozens, if not by hundreds of scientific publications, articles prepared and distributed in Russia (https://www.consilium.europa.eu/nl/documents-publications/library/library-blog/posts/separatism-in-europe-1-c haracteristics-of-separatist-movements/. 2019) in Afghanistan (.Mohak Mohammed. 2019), in African countries (https://www.dw.com/en/beyond-catalonia-separatist-movements-in-western-europe/a-40761144. 2019) and, of course, in dozens of other countries.

It turns out that the problems and contradictions are not so much in extremism and separatism, or rather, not only in separatism. Questions and answers related to the meaning and role of separatism, the goals it serves and the tasks it resolves are of great relevance and need. It is also the question of who is behind it and with what consciousness and thinking. And most importantly, to what extent this very separatism is embedded in the historical and political specifics and features not only of this time, but also of the wider era. And how does the historical and political tradition affect the consciousness, thinking and behavior of people, not only strengthening and revitalizing, but also distorting both consciousness and thinking. And ready therefore to neglect and even to give up their identity and stand in one row on the basis of extremism and separatism with their blood, political and ethno-religious antipodes.

Perhaps it would be easier to combat aggressive forms of extremism and separatism, and meet legitimate or historical and mental needs, if separatism remained only in the spheres of philosophy, history and identity. But no, extremism and separatism are more or less directly linked to everyday politics and its historical consequences 
and manifestations and even in the field of sharp polemics it is connected not only with scientific debates, but also with debates between categories and groups of citizens, not so enlightened and compliant.

It should be borne in mind that the content of extremist and separatist sentiments and corresponding behavior is formed by the society in different countries on the basis of fake information or information presented as such. If we talk about populism and propaganda cliches of such type, here is a vivid example: In 2017, Yana Prussakova presented a study on the pages of Фонтанка.fi “...not about the content and facts, but about how factory of fake news works." The reason was that in Yandex-Zen "surfaced a post allegedly by a Finnish blogger who shocked Facebook by the statement that "half of the world owes Russia for life." It was followed by a list of historical facts with dates showing when and under what circumstances different states gained independence "from the hands of Russia" (The greatness of Russia through the eyes of fake Finnish bloggers). This allegedly Finnish fake blogger named more than thirty countries of the world, the fate of which is connected with the history of Russia. And comes to the conclusion that Russia (and the USSR) “...consistently under all governments upheld the principles of independence and self-determination of nations and peoples, in every way helping to create a multipolar world in any era and very often, unfortunately, at the same time sacrificed its own interests, the interests of the state and its people."

Such fake information, the nature of its distribution (Burgen Stephen, Jones Sam. 2019), and a substitute author (https://warsawinstitute.org/p1/zamrozone-konflikty-w-strefie-postsowiec... 2016) could lead to nothing but recognition of all elements of this information as fake and used for propaganda purposes. But the discussion of this news and comments on it bring us to another level of analysis. The topic and the ways of its interpretation demonstrate the movement from populism and propaganda cliches to the facts, their completeness and truth. For example, on 21 December 2017, at 6.34 p.m. LapsSuomen carried a post: "Thank you, Yana! You have professionally studied the topic of fake news and as an example cited works of pro-Russian fake bloggers. Can you cite examples of pro-Western, pro-Ukrainian or pro-Finnish bloggers?" The same line was continued on December 22, 2017 at 5. 40 p.m. by another blogger (The greatness of Russia through the eyes of fake Finnish bloggers (The greatness of Russia through the eyes of fake Finnish bloggers): "The post was carried on July 8, 2015 by this site: https://vk.com/wall-72671313_342950 by Veikko Korhonen. The personality was taken from: https://www.is.fi/viihde/art-2000000463550.html, the date of publication is December 29, 2011. As to the facts cited in the post, nobody disagrees. Try to challenge the facts."

These seemingly convincing examples and techniques of populism, the clash of opinions around extremism and separatism slide in fact past the essence of the problems and the larger and distorted order of their interpretation.

\section{The New in Extremism and Separatism as a Natural Tool of "Divide and Rule" Policy}

The political essence and fate of extremism and separatism today is not only a reflection and expression of some part of the political realities associated with migration, the participation of separatist parties in electoral processes, economic turmoil, the formation of territories beyond the control of the central government, under the tutelage of the separatists. Separatism and its extremist manifestations in various forms have given rise to whole scientific schools, whose representatives, scientists, specialists and experts in various fields of knowledge study and analyze this phenomenon. They look for its distinctive features of global, continental, regional and country scale. Where do these searches lead, and whether it is possible to find at least the main directions of thought and the process of separatism? Here is a sample of one of the directions followed by Katharine Boyle from the Cornell University and Pierre Englebert from Pomona College: "Unlike the currently popular economic model of civil wars, we find that political factors overshadow other approaches. Specifically, groups in failed and transitioning states, those who control or have historically controlled autonomous institutions, and those who face discrimination are more likely to resort to extremism and separatist violence. We do not find reliable effects of "greed" or other economic theories. Finally, existing models tend to over-predict recessions in Latin America and Africa. We offer explanations and call for a new understanding of the political nature of separatism as opposed to other types of civil wars (Boyle, K., \& Englebert, P. 2006). In 2013, essays on political analysis of separatism and secession were published, they covered cases from the Balkans, the USSR, Britain and the Basque Country to Sri Lanka, Burma, China, Tibet and Taiwan. Similarities and differences in the processes and outcomes of separatist-secessionist movements in Europe and Asia have been identified relating to how separatist movements receive support and mobilize their target populations, and how central governments and political bodies respond to challenges (https://books.google.ru/books/about/The_Question_of_Separatism.html?hl=ru\&id=FBA3YgEACAAJ\&output= html_text).

If such ideas are not idealistic fancies, then even in them, if one wishes one can discover the failure of any 
reconciliation with reality. It is absurd for separatists to reconcile themselves with something whose meaning and purpose are not clear to them and are waiting for their understanding. They are against reconciliation not even because of stubbornness. Hence, it is not enough to say that political separatism is multifaceted. Or somehow make it even more uncertain, and then develop a scientific discussion around this uncertainty. Theoretical problems exist and will remain. But this is not an empirical problem. As for the empiricist, the problems are concentrated where the old ideas about it have lost the ability to be a true reflection of its empiricism, but they are dear to the social and political psyche and physiology, and new promising beliefs have not yet had time to determine. And scientists are still looking for ways to learn the practice and theory of separatism. And dwell on the problems of the growing involvement of European institutions in the case against the Catalan separatists (https://en.wikipedia.org/wiki/List_of_active_separatist_movements_in_Africa) Or on the recognition that the study of the context of Scotland's relationship with the EU can help to draw interesting conclusions about the nature of the EU and British constitutionalism (https://link.springer.com/chapter/10.1057/978-1-137-59426-6_29. 2019).

It's a fact that political extremism and separatism is relevant and even more important than any other instrument of mobilization or destabilization for the purposes of its counterparties on a global, regional or national scale; and in the conditions of the impending new global crisis it is a common version of the world political sociology view on this process. To do it, just look at regionalism in the European Union, the tribal and Islamic radicalism of the Middle East, the African continent, where tribal loyalty often exceeds national, Ukraine, Russia, Afghanistan, China, and dozens of other countries on all continents, where the fight against extremism and separatism has been and remains the quintessence of domestic politics, or where extremism and separatism is a cover for the interests of governments, political parties, financial centers and groups of influence, their constant struggle for power and its retention. It seems that the correctness and truthfulness of such judgments is confirmed even in the quantitative data circulating in the scientific circulation. An incomplete list of historical separatist movements around the world contains 100 entries. The compilers of such list report that most separatist movements do not achieve their goals so they list only the most notable ones (https://researchers.mq.edu.au/en/publications/secessionism-and-separatism-in-europe-and-asia-to-have-a-state.

2019). According to incomplete estimates, today, there are 50 main centers of separatism in the world, together they occupy an area of 12.7 million $\mathrm{km} 2$ with a population of 220 million people. Researchers identify six types of geographical separatism with an unknown number of foci: eight in Western European, 12 in Eastern Europe, six in Islamic countries, fourteen in Asia, six in Africa and four in America. At the same time, there are armed conflicts in 20 hotbeds, especially typical for Asia. There are several dozens of places fighting for separatism in other parts of the world (https://www.chinadailyhk.com/articles/172/227/108/1570636452363.html. 2019). The words and expressions associated with this concept have more than 70 meanings, among which you can find such as: extremism, terrorism, Islamism, Hetmanate, European integration, ethno-nationalism, federalism (https://www.chinadailyhk.com/articles/172/227/108/1570636452363.html. 2019) and others.

Further, we also see the continuation of the same line of reasoning, indicating only one factor, the factor of the growing and frightening penetration of extremism and separatism into the structure of politics and social life. "The growth rate of separatism over the last century has more than doubled (Ukraine Today. 2019), wrote Associate Professor of Political Science at the University of Minnesota Tanicya M. Fazal in Foreign Affairs. At the same time, for some countries and territories it is already a relic of the past, for some - it is an acute problem, and for others - it is an unexpected future. "Separatism in the "Island of Beauty" (Corsica) is becoming an increasingly marginal phenomenon" (Palivoda Volodymyr. 2019), wrote Yu.I. Rubinsky, Doctor of History, Head of the Center for French studies of the IE RAS in the article "Corsican nationalism and its limits." And Flemish separatism, which is more than a hundred years old, in the last two decades "has turned from a latent phenomenon into a significant political phenomenon visible to the outside observer" (https://news-front.info/2019/10/16/pushilin-dlya-mira-na-donbasse-i-peremen-na-ukraine-nuzhno-polnostyu-ras pustit-vse-vlastnye-struktury/). According to the corresponding member of RAS, Deputy Director of IE RAS M.G. Nosov "unfortunately today there are few political events that are not related to the problems of separatism" (Nawazish Elias. 2019).

It follows, that the today world order is a natural environment for those processes that are supported by extremism and separatism and for those political regimes, governments, political parties and movements that use separatism and separatists for their own purposes, whose essential function is to separate and divide (https://www.economist.com/europe/2019/11/07) peoples, states, civilizations, ethnic groups, religions, cultures, etc. That is why political extremism and separatism are relevant not only in academic and practical terms. Today, like no other political instrument, they serve excellently and ensure the implementation of the idea of effective 
and efficient governance, tested by ancient civilizations - divide and rule. And this is despite the fact that political extremism and separatism have a negativist contextual coloring in the public consciousness and among most of the political establishment.

\section{New Political and Polemical Atmosphere for Understanding Separatism}

Today, it is no enough to explain political separatism and related violence as "multifaceted and dynamic fluidity" (https://www.reddit.com/r/MapPorn/comments/73vipn/support_for_separatism_in_europe_oc_1092_x_1424.

2019). No matter how original was the idea expressed by the already mentioned scientist M. Nosov about "fake separatism," it only helps in explaining the new motives and causes of separatist activity. Someone wants to consider Brexit in the same vein as a new form of separatism, i.e. British separatism, the willingness of the British elite and British society to separate themselves from the European Union. It is strange that Russian scientists who have survived the collapse of the USSR and described the extreme forms of separatism already within the Russian Federation said in 2015 that without claims to comprehensive coverage of the topic, they wanted to show that the separatist challenge, although irrelevant at the moment, cannot be considered deleted from the agenda. After reports and discussions on the topic "Separatism in the political life of modern Europe" which took place on June 3, 2015 at the Institute of Europe of the Russian Academy of Sciences, a collection of works was prepared which analyzed the separatist manifestations in the political practice of the European states after the failure of the referendums on the independence of Scotland and Catalonia. In this context, the political potential and electoral positions of separatist parties and organizations (based on polls and election results), their strategic goals and tactical objectives were assessed. The degree of popularity of separatist aspirations and the likelihood of their implementation, the reaction of influential internal and external actors were considered (Palivoda Volodymyr. 2019).

If you look at the topic of political separatism carefully, then, in our view, more relevant and topical in the theoretical and pragmatic aspect will not only be detailed and thorough description of the causes of separatism, not associated with it directly, but infused with separatism, new consciousness, emerged of separatism. In the study of separatism scientists Bertrand M. Roehner and Leonard J. Rahilly suggested new research approaches. "The novelty of the present approach lies in the following simple but unconventional approach: (1) we study clusters of events rather than individual events. So we're trying to give our study some predictive power. If twenty separatist movements of a certain type have all failed, it is likely that the twenty first will also fail; (2) we focus and answer the question "how?" and not the question "why?" that is so dear to historians; (3) separatism is a multifaceted topic... That is why we focus our attention on a certain class of social group, the so-called national minorities. In addition, as far as possible, we will limit ourselves to such phenomena for which quantitative data are available" (Roehner, B. M., \& Rahilly, L. J. 2016).

The reflection of political separatism in this spirit is confirmed by many facts. If at the time of its creation the UN united 51 states, in 2018 it united 195 independent states (193 UN member states and 2 observers). Also on the political map of the world there are: seven unrecognized or partially recognized states that are not UN members, but are officially recognized by one or some UN member states; four non-UN states that are not recognized by any UN member state, but recognized by some partially recognized states; 46 possessions with permanent, indigenous population and their own citizenship, 3 territories with special status stipulated in international agreements, 35 dependent territories with permanent population, 8 overseas territories considered an integral part of the respective states, but sometimes classified as separate possessions (Kandel, P. E. 2015).

Not all of these states are the products of the cause-and-effect relations and relations of a purely separatist nature in the concept of secession. Some and even many of them are the result of separation by agreement or arrangement. It is believed that about half of today's UN member states had their origins as breakaway states, including the US (https://www.theepochtimes.com/separatism-in-europe_2487511.html. 2019). Consequently, the process of preserving the territorial integrity of states and the formation of new states on the same territories within certain limits develops according to its own laws. Such process can hardly be reduced to the fact that it is a multifaceted and dynamically flowing process. But the problems and issues associated with this process are not as simple as they seem at first glance. But it's not worth it to complicate them to a certain limit. Extremism and political separatism can be analyzed and its essence can be understood. There are significant results in the cognition of political separatism. It no longer takes more than to understand the nature of separatism, its signs and types. If there are obstacles in this way, they are connected with such questions as "who" and "for what purpose" uses separatism. Of course, whatever type of separatism is taken as a subject of study, in each of them one can now observe that supporters and opponents of separatism trade places; accusers and perpetrators of separatism in reality very often appear not by themselves, or not what they claim to be and not who they really are. 
Today, researchers, analysts and specialists are no longer surprised when they hear the interpretation of separatism in terms of a political program of the requirements of formal separation from an UN-recognized state of a part of the territory in order to create a new state. Even if this demand, conceived by ideologists and supporters of such program, receives recognition from other states (https://en.wikipedia.org/wiki/List_of_historical_separatist_movements. 2019). All such aspects of separatism are popularly interpreted. And in so far as they go hand in hand with real extreme political processes, in so far as they state the views and positions held by the governments of countries where separatism is present and separatist parties and movements in these same countries. But this is the hitch (the problem) we have to emphasize because separatism is inevitable for many countries. And the options are offered, how to resist it, or, on the contrary, how to use it. That's right. But that's not all there is to know. And supporters of separatism and its sworn opponents will not act as before.

The entire world system has entered a new era. And it turned out that separatism is much more deeply connected not only with the nature of modern politics and socio-political process, but also with the nature of the development of these processes in a particular region or country. And with the style of its interpretation and interpretation on the example of continents, regions, individual countries and even territories of individual countries. As with its motley interpretation by various scientific schools, groups of scientists and analysts. We are talking not only about the geography of the distribution of the pockets of separatism and a simplified model of its representation, such as-armed or not-armed pockets. We can confidently say that only the European continent is represented by several groups of separatism researchers, among which the group of Western Europe (https://networks.h-net.org/node/3911/discussions/90459/secessionism-and-separatism-monthly-series-secessionand/) and Eastern Europe (https://www.researchgate.net/publication/268460099_Explaining_Separatist_Violence_Multi-Faceted_Dynamic _Fluidity. 2019), stand out. In 2014, the Council of Europe influenced by the referendums on independence or elections in Catalonia, Scotland and Belgium, and heated debates around these processes, said that the blog "Separatism in Europe" will feature four posts analyzing ideological, political and economic aspects of separatist movements in Europe. The first of them concerned the general characteristics of separatism (https://kartaslov.ru/). Subsequent posts dealt with possible scenarios (2), new states and EU membership (3), political and economic consequences of separatist and extremist manifestations (4).

In such conditions, groups of scientists even more actively than before study the topic of separatism. Although the journal "Ethnopolitics" in 2013 published six articles, which analyzed various aspects of separatism.

The phenomenon of separatism has too many dimensions to allow a universal theory or concept. Many researchers stumble upon this difficulty. It seems that the scale and significance of this phenomenon in the structure of politics and political relations is weightier and more significant than it is presented in the studies. Nevertheless, if we talk about the European model of separatism research in general, its supporters, ideologists and propagandists, in our opinion, excessively raise separatism to such a level that it seems to change the entire political landscape in the regions that yesterday seemed to be resistant to the ideology, policy and practice of separation or division. A striking example of this position is the Bulgarian scientist Ivan Krastev, who wrote: "the migration crisis not only upset the balance of right and left forces in the European politics and shattered the liberal consensus that set the tone on the continent for decades, but provoked an identity crisis across the political spectrum and turned upside down the very beliefs with which the European Union justified its existence" (Krastev, I. 2020).

Very motley reality and reality in the form of stable opinions and preferences of not only scientists and researchers are imposed on this kind of reasoning and ideas. It is important, but especially important is the opinion and preferences of the civil society. The development of such process leads to the fact that, first of all, a group of scientists, specialists and experts is actively working in the space of Western Europe, and some of them believe that a) an ambiguity between autonomy and independence prevails among the main separatist movements in Europe, including some of the most stable; b) "historically separatism was more regional, now it is anti-EU"( https://www.thefreedictionary.com/separatism.2019) nonviolence now seems to be the rule, there has been a transition to political procedures for conflict resolution, but this situation can change quickly; d) the issue of separatism in sovereign states is primarily the result of the clash between national and regional identities with larger, global entities perceived as distant, alien and oppressive; e) governments and leaders should address the root causes of separatism, not reject them.

It is important for other researchers to show in their numerous studies not only the growth of the number of separatist movements in Western Europe (Catalonia, Scotland, Flanders, Corsica and even Bavaria, etc.), but also to emphasize the differences in the opinions and preferences of citizens; between the proportion of those who are 
for independence and secession, and who are against it. A lot of unimportant things are written on this topic in sociology. However, if you conduct a survey in any region of the world, some experts adhere to this version of thinking, you will get between 5 to 10 per cent of respondents who would like to separate. Corsica has a strong nationalist movement that has actually won the elections, while in Sardinia in 2014 nationalist candidates received a combined 20 per cent of the vote and joined the Italian national parties. While Corsican support for independence is 20 per cent, in South Tyrol there is little difference between independence and reunification. By region and country, the data can vary significantly in one direction or the other, for or against secession. If we are right in interpreting these data, it seems that such percentages should not be considered as serious sentiments for secession. Especially, if those percentages are not backed by supporters with real plans for secession. A much larger number would rather express a preference for secession. In surveys on separatism, we cannot exclude situations in which there are those who would say: "Yes, I want my region to secede, but I would never do anything for it" (https://www.belvpo.com/44305.html/. 2019)

It does not add much to the understanding of modern changes in this process to state that for some countries and territories it is already a relic of the past, for others it is an actual problem and for others it is an unexpected future. Nevertheless, the one or the other does not weaken, but only strengthens the controversy, when we find statements and judgments of this kind.

In the European experience of social and political practice, scientists, specialists, active citizens see that there are many regions which have their own mentality and differ in opinions and preferences. No one should be surprised by this, as there are always minorities with such sentiments. But most of them do not have a development plan if they separate. Many and many of those who would like to separate see the looming security threats and economic problems (https://thequestion.ru/questions/366336/answer-anchor/answer/518542?), including those connected with no access to the sea. The most resolute opponents of secession and division propose: a) getting rid of all these small peoples by including them in the European Republic with 50-60 regions and granting them all rights; b) that each region should send two senators to the European Parliament; (c) that the European Parliament should gain real power, with all Europeans electing one head of the United European state. From such radical proposals one can come to the equally radical conclusions: a) there is no need for division; b) now only such policy will guide the nation; power will be in the hands of all Europeans not only Germany, Great Britain and France.

Eastern European separatism, in contrast to Western European separatism, has at its core the consequences of the collapse of communist regimes and the Soviet Union. As the researcher Timofey Agarin writes, in the Baltic States this peculiarity manifests itself as a discontent with the policies, institutions and regimes of both ethnic minorities and their elite groups and the distortion of the interests of these very minorities in the post-Communist Baltic States (https://www.facebook.com/politbear/posts/1462086103923965.2019).

In such an environment, on the one hand, we see populism and popularity of separatism and, on the other (and it turns out to be a surprise), populism and popularity of its opposite - unification and integration, and intellectuals like Ivan Krastev combine the ability to idealistic distraction with a strong intuitive sense of reality on the example of what is happening in the European Union. In developing and broadcasting theories of European integration, they miss the underlying motives for division and fail to create an updated theory of European disintegration and separatism. This leads to a number of serious problems and contradictions with regard to the manifestations of separatism and its interpretation, for example, in Eastern Europe and especially in Ukraine.

The division of the USSR, Yugoslavia, Sudan, Ethiopia, Georgia, and Moldova, the fragmentation of Syria, Iraq and Libya are a perfect illustration of the characteristics of modern forms of separatism, its causes and consequences. The most striking example of the manifestation of the separatist protest movement, rolling like waves and gaining the scale of a tsunami are the events of October 2019, when the leaders of the Catalan separatists, sentenced in Spain to the prison terms of 9 to 11 years, received support from the supporters of "rebel autonomy" and from the centers of globalism. Catalans' desire for independence has plunged Spain into the biggest political crisis over the past 40 years. There are not enough events to understand the Spanish-Catalan separatism. Catalan separatism is still in motion. And it is still early to sum it up.

Another type of perception, another nature, motivation and policy of separatism, not less interesting for the study is connected with the role of Russia in separatist activities in the territories adjacent to Russia. We have a peculiar scheme and style of modern interpretation of these processes. The chief consultant of the security sector development of the Department of the National Institute for Strategic Studies (Ukraine) Volodymyr Palivoda in his article "Frozen" conflicts in the post-Soviet space as a challenge to European security" in mid-2019 wrote: "... conflicts of this kind occur in regions beyond the control of the central government, under the control of 
separatists" (Kandel, P. E. 2015). A repetition of this same logic and thinking, with an even greater emphasis on political engagement, is found in the works of other researchers. "For many years there has been talk of globalization blurring national boundaries and making areas culturally homogeneous. However, the desire to create new states based on ethnicity, language or culture has not disappeared. Separatist sentiments exist on all continents," says expert and journalist Reetta Vairimaa from the University of Helsinki. And here she says that the international community is reluctant to support the pursuit of independence on the basis of language or culture, because ethnic nationalism carries the risk of a major violent conflict. He adds that "Russia supports separatism abroad, but not at home" (Independence. 2019). The same conclusion is reached by one of the publications, interviewing in 2016, the then President of Georgia Giorgi Margvelashvili: "it is not surprising that Russia supports separatists in reform-oriented countries, all of which actively seek closer relations with the EU: Ukraine, Georgia and Moldova." Yevgeny Ryabinin, a researcher from Mariupol (Ukraine), views separatism in Donbas as an ethnos-separatist conflict, the dynamics of which are influenced by Russia, which supports "the rebellious region through diplomatic and military means, providing the rebels with military equipment. In addition, Russia provides the population of the rebel territory with humanitarian aid and textbooks for schools." The United States also "support the government of Ukraine." Developing his idea, Ryabinin considered it necessary to state that both sides support the idea that the rebellious region should remain the territory of Ukraine. But Russia insists on granting this region an autonomous status. The US is not officially involved in the negotiation process on the ways out of the ethnic separatist conflict, but its allies Germany and France are. Today, the rhetoric has changed and European states are forcing Kiev to comply with the Minsk agreements, although a few months ago such pressure was not so strong (https://www.e-ir.info/2013/05/20/on-separatism-in-latin-america/. 2019).

Indeed, the reality is that Ukraine, one of the largest states in Europe, has also been plunged into the biggest crisis in the last five years by separatism. Is it by chance that Ukrainian separatism (Ryabinin, Y. 2017), separatism in Ukraine (Palivoda Volodymyr. 2019), die and then reborn again, and remain "more alive than alive"? We can agree with the maxim that this is the deepest pattern of development of modern Ukrainian statehood. If both sides of separatism in Ukraine do not see clearly the phenomenon itself, its origins and nature, no one will explain anything to both sides. Their eyes and their minds are implacable and turned to themselves. Their trust is at zero. Only military actions or destructive protests, the fight against the overwhelming forces of the enemy, the aggressiveness of separatism is fully revealed and they start to realize what is happening and its futility.

If we give a generalizing view of the political and polemical atmosphere that accompanies separatism, we find that so far the researchers have spoken casually not only about conventional types of separatism, and how it is transformed, but also about "fake separatism" or "virtual separatism", as an unprecedented style and methods of functioning of separatism. It seems that this is the actual direction of the study of modern separatism. But here, it turns out that it cannot be done without paradoxes. The paradox for even greater curiosity and interest may not be the explanation of the stencil formats of the analysis of separatism: its causes, factors, driving forces, their interests and goals achieved through this political action. Already, it seems it has lost the status of novelty and the approach in which separatism is studied as a cluster of events, rather than individual events, as recently stated by a group of foreign researchers (Roehner, B. M., \& Rahilly, L. J. 2016). And not only fake or virtual separatism excites the minds of scientists and researchers. The paradox is that the antipodes of separatism real or normative, conventional or virtual, are already becoming its new forms. Separatism today appears to the researcher not only in its strong, authentic form, but also in a weak one. A weak form can distort the essence and meanings. It can be effective and efficient, and also spectacular. Political extremism and separatism became a platform for testing and testing previously unprecedented effects, twisted into a single knot of political will and the effects of art on the psyche, behavior and minds of citizens.

\section{Discussion}

There is nothing in political extremism and separatism that does not contain both direct and indirect separatism together. Direct separatism in itself is an empirical world, a set of phenomena, the existence and connection of which is reflected in the representations expressed through images, concepts and terms. Therefore each epoch, each ideology dominating in science and public consciousness, create the separatism and its representation. Globally, such views were influenced by the crisis of postmodernism, post-nationalism, secularism, identity, globalism in the first quarter of the 21 st century. All these events, experiencing a systemic crisis, interpreted as a disintegration are only a euphemism of the process, which, as we believe, has long been defined by the term "separatism"!

Indirect separatism is a definition and terminology, the use of which today is confusing and can lead to 
misunderstanding and be harmful and even dangerous in justifying certain decisions. Examples of such mistakes and decisions are the connivance of politics with the use of troops, nationalist, de jure legal, and de facto semi-legal and illegal military formations, army means of destruction with their declared separatists "half-brothers" and "separatists," which are such only in the minds and perceptions of radical nationalists and extremists. Given the specificity that is characteristic of different countries in the context of separatism and extremism, we can confidently say that:

Firstly, separatism in the new edition is often a "Fig leaf" covering civil war, extremism and terrorism, brutal violence, radical nationalism and unitarianism for elites and groups of influence who declare themselves an indigenous nation, and who themselves actively exploit the ideas and programs of separatism. But having seized power, they do not even allow administrative, political and cultural autonomy for other ethnic groups of the population;

Secondly, Russian researchers and analysts have yet to explain why Russians by blood and language are fighting hard against each other in the separatist conflict in Ukraine. And inside the country, the urgent task is not only to rise to the level of traditionalism developed and tested by history, that would be enough for the doctrinaires of patriotism and internationalism, but also to look for direct and strongest motives for an active anti-separatist policy in the state and internal relations of the peoples of Russia.

For the countries of Asia, the peoples, ethnicities and tribes of Africa-a serious and fundamental question is not only what causes and motivates political extremism and the growth of extremist thinking around the world. A pressing theme for this region and for individual countries like Afghanistan is the desire to understand and explain for themselves the main motives for the expansion of political extremism in Afghan society and African countries. An important issue is also whether it is possible to reformat them with the balance of external and internal political and military-economic forces that has developed in the world at the present time.

\section{References}

Agarin Timofty. Resident Aliens? Explaining Minority Disaffection with Democratic Politics in the Baltic States. Retrieved from https://www.tandfonline.com/doi/full/10.1080/17449057.2012.748247

Bill Thomas. Hide Comments. Retrieved from https://www.merriam-webster.com/dictionary/separatism

Boyle, K., \& Englebert, P. (2006, March). The primacy of politics in separatist dynamics. In annual meeting of the international studies association, San Diego.

Burgen, S., \& Jones, S. (n.d.). New generation, new tactics: the changing face of Catalan protests. Retrieved from

https://www.theguardian.com/world/2019/oct/18/new-generation-new-tactics-the-changing-face-of-catalanprotests

Jacobs, J. (2011). The Question of Separatism: Quebec and the Struggle over Sovereignty. Baraka Books. Retrieved

from https://books.google.ru/books/about/The_Question_of_Separatism.html?hl=ru\&id=FBA3YgEACAAJ\&out put $=$ html_text

Jean, P. C., \& Aleksandar, P. (n.d.). Secessionism and separatism in Europe and Asia: to have a state of one's own. Retrieved from https://researchers.mq.edu.au/en/publications/secessionism-and-separatism-in-europe-and-asia-to-have-a-sta te-of

Kandel, P. E. (2015). Separatism in the political life of modern Europe. Moscow: In-t Evropy RAN (Reports of the Institute of Europe).

Krastev, I. (2020). After Europe. University of Pennsylvania Press.

Medvedev, N. P., \& Kamara S. (2018). Problems of Ethnoseparatism in Africa: National Liberation Movement of Azawad (MNLA). Eurasian Union: Issues of International Relations, 1(23), 17-24.

Mohak, M. (n.d.). The fight against terrorism and the reconciliation with extremism: politics after September 11. Retrieved from https://www.bbc.com/persian/afghanistan-45475661

Nawazish, E. (n.d.). Why should we worry about the spread of extremism in Afghanistan? Retrieved from https://www.etilaatroz.com/43860/

Nicolás, Z. (n.d.). The Increasing Involvement of European Institutions in the Case against Catalan Separatists.

Retrieved

from 
http://opiniojuris.org/2019/06/20/the-increasing-involvement-of-european-institutions-in-the-case-against-c atalan-separatists $\% \mathrm{EF} \% \mathrm{BB} \% \mathrm{BF} /$

Palivoda, V. (n.d.). "Frozen" conflicts in the post-Soviet space as a challenge to European security. Retrieved from https://niss.gov.ua/en/node/170

Pavković, A. (n.d.). Secessionism and Separatism Monthly Series: "Secession and Secessionism". Retrieved from https://networks.h-net.org/node/3911/discussions/90459/secessionism-and-separatism-monthly-series-seces sion-and

Roehner, B. M., \& Rahilly, L. J. (2016). Separatism and Disintegration. A Comparative investigation.

Ryabinin, Y. (2017). The basic causes of the contemporary separatism. Journal of Geography, Politics and Society, 7(1), 5-9. https://doi.org/10.4467/24512249JG.17.001.6200

Sabrina, M.-P. (n.d.). Beyond Catalonia: Separatist movements in Western Europe. Retrieved from https:/www.dw.com/en/beyond-catalonia-separatist-movements-in-western-europe/a-40761144

Sanchez, P. (n.d.). Catalonia, Spain, and Europe are Better Together. Retrieved from https:/www.project-syndicate.org/commentary/catalonia-separatism-violates-democracy-rule-of-law-by-pe dro-sanchez-2019-11

Semenenko, I. S. (2018). Nationalism, Separatism, and Democracy. New Patterns of National Identity in "Old" Europe. - Polis. Political Studies, (5), 70-87.

Separatism in the political life of modern Europe. Moscow: Institute of Europe RAS, 2015.

Serrano, I. (n.d.). Just a Matter of Identity? Support for Independence in Catalonia. Retrieved from https:/www.tandfonline.com/doi/full/10.1080/13597566.2013.775945?scroll=top\&needAccess=true;

Sionaidh, D.-S. (n.d.). Scotland, Secession, and the European Union. Retrieved from https://papers.ssrn.com/sol3/papers.cfm?abstract_id=3316715

Tanicya, M. F. (n.d.). Why Rising Separatism Might Lead to More Conflict. Retrieved from https:/www.foreignaffairs.com/articles/2018-06-14/go-your-own-way

Thieß, P. (n.d.). Separatism in Europe: A Lose-Lose Situation? What economic consequences do we have to fear? Retrieved from https:/ged-project.de/ged-blog/improving-public-understanding-of-economic-globalisation/separatism-in-e urope-a-lose-lose-situation/

Webb, M. J. (n.d.). Explaining Separatist Violence: Multi-Faceted, Dynamic Fluidity. Retrieved from https://www.researchgate.net/publication/268460099_Explaining_Separatist_Violence_Multi-Faceted_Dyn amic_Fluidity

Yazykova, A. A. (2015). Separatism in the political life of modern Europe. The Institute of Europe RAS.

Zhou, B. J. (n.d.). Revision of HK's core values needed to resist separatism. Retrieved from https://www.chinadailyhk.com/articles/172/227/108/1570636452363.html

\section{Copyrights}

Copyright for this article is retained by the author(s), with first publication rights granted to the journal.

This is an open-access article distributed under the terms and conditions of the Creative Commons Attribution license (http://creativecommons.org/licenses/by/4.0/). 